\title{
Analysis of rock mass dynamic impact influence on the operation of a powered roof support control system
}

\author{
Dawid Szurgacz ${ }^{1, *}$, and Jarosław Brodny ${ }^{2}$ \\ ${ }^{1}$ Center of Hydraulics DOH Ltd, 147 Konstytucji St., 41-906 Bytom, Poland \\ ${ }^{2}$ Silesian University of Technology, 26-28 Roosevelta St., 41-800 Zabrze, Poland
}

\begin{abstract}
A powered roof support is a machine responsible for protection of an underground excavation against deformation generated by rock mass. In the case of dynamic impact of rock mass, the proper level of protection is hard to achieve. Therefore, the units of the roof support and its components are subject to detailed tests aimed at acquiring greater reliability, efficiency and efficacy. In the course of such test, however, it is not always possible to foresee values of load that may occur in actual conditions. The article presents a case of a dynamic load impacting the powered roof support during a high-energy tremor in an underground hard coal mine. The authors discuss the method for selecting powered roof support units proper for specific forecasted load conditions. The method takes into account the construction of the support and mining and geological conditions of an excavation. Moreover, the paper includes tests carried out on hydraulic legs and yield valves which were responsible for additional yielding of the support. Real loads impacting the support unit during tremors are analysed. The results indicated that the real registered values of the load were significantly greater than the forecasted values. The analysis results of roof support operation during dynamic impact generated by the rock mass (real life conditions) prompted the authors to develop a set of recommendations for manufacturers and users of powered roof supports. These include, inter alia, the need for innovative solutions for testing hydraulic section systems.
\end{abstract}

\section{Introduction}

The number of mining tremors occurring in Polish mines has significantly increased in recent years. It is caused by mining exploitation carried out at grater depths. In 2016, at output of 70.4 million tonnes of hard coal, as much as 36.9 million was acquired from longwalls exploited in hazardous conditions of rock mass tremors. With regard to total production, it was over $50 \%$ [1]. A comparison of the amount of coal extracted with the number of high energy tremors and accidents in the Polish hard coal mines in 2006-2016 is presented in Table 1.

\footnotetext{
" Corresponding author: dawidszurgacz@doh.com.pl
} 
Table 1. Extraction, number of high-energy tremors, rock bursts and accidents in Polish hard coal mines [1].

\begin{tabular}{|c|c|c|c|c|c|c|c|}
\hline \multirow[t]{2}{*}{ Year } & \multirow[t]{2}{*}{$\begin{array}{r}\text { Extraction } \\
{[\mathrm{mln} \mathbf{M g}]}\end{array}$} & \multicolumn{2}{|c|}{$\begin{array}{l}\text { Output form } \\
\text { seams with tremor } \\
\text { hazard, mln Mg }\end{array}$} & \multirow{2}{*}{$\begin{array}{c}\text { No. of } \\
\text { tremors } \\
\geq 1 \times 10^{5} \mathrm{~J} \\
\text { (acc. to } \\
\text { GIG) }\end{array}$} & \multirow[t]{2}{*}{$\begin{array}{l}\text { No. of } \\
\text { rock } \\
\text { burst }\end{array}$} & \multicolumn{2}{|c|}{$\begin{array}{c}\text { Accidents } \\
\text { caused by rock bursts }\end{array}$} \\
\hline & & [mln Mg] & {$[\%]$} & & & fatal & total \\
\hline 2006 & 95.2 & 42.1 & 44.2 & 1,177 & 4 & 4 & 20 \\
\hline 2007 & 87.5 & 40.5 & 46.3 & 939 & 3 & 0 & 10 \\
\hline 2008 & 83.6 & 41.9 & 50.1 & 917 & 5 & 0 & 26 \\
\hline 2009 & 77.4 & 34.3 & 43.8 & 772 & 1 & 0 & 6 \\
\hline 2010 & 76.1 & 35.8 & 47.1 & 1,206 & 2 & 2 & 15 \\
\hline 2011 & 75.5 & 34.2 & 45.3 & 1,034 & 4 & 1 & 17 \\
\hline 2012 & 79.2 & 37.6 & 47.47 & 1,022 & 1 & 1 & 2 \\
\hline 2013 & 76.47 & 36.9 & 48.25 & 1,427 & 1 & 0 & 5 \\
\hline 2014 & 72.5 & 36.0 & 49.58 & 1,765 & 1 & 0 & 0 \\
\hline 2015 & 72.2 & 37.1 & 51.39 & 1,322 & 2 & 2 & 2 \\
\hline 2016 & 70.4 & 36.9 & 52.41 & 1,640 & 1 & 1 & 3 \\
\hline
\end{tabular}

The analysis of data presented in Table 1 allow to conclude that despite the decrease in level of coal mining extraction, the number of recorded tremors increases. As a consequence, the level of hazard of coal mining is greater. This in turn forces the need to apply appropriate protection of mining excavations against these dynamic impacts. The equipment used to secure mining excavations is a mining roof support. In the case of longwall excavations, these are powered roof supports. Their task, apart from ensuring the safety of the crew and the protection of the equipment in the mining area, is to facilitate the process of mining the rock mass.

One of the important factors influencing the reduction of effects caused by the dynamic impact of the rock on the support is the proper co-operation of the roof support with the rock mass [2-4]. During the dynamic impact of the rock mass, the powered roof support should ensure the support and prevent loss of contact with the roof and excessive convergence of the excavation $[5,6,7,8]$.

Hydraulic legs with the safety system are the most important factors impacting on safety and proper operation of the powered roof support. The safety system is the basic support element of the roof support, which determines its performance $[5,7,8]$.

The requirement that must be met in order for a powered roof support to be accepted for mining exploitation is the provisions of the Regulation of the Minister of Energy on Occupational Safety and Health dated November 23, $2016 \S 523 \mathrm{sec}$. 2. The provisions state that a powered roof support designed to operate at longwalls exploited in the areas of mining tremors occurrence shall be adapted by yielding to absorb dynamic loads. The hydraulic system of the leg and the control system should conform with the requirements included in the Machinery Directive and harmonised PN-EN 1804 standards [9].

The system was analysed taking into consideration the role, importance and functions that must be fulfilled in the excavation by the powered roof support and the importance of the hydraulic system. The analysis included tests on hydraulic legs and a control system dynamically impacted by free falling impact mass. The time course of the pressure in the leg was determined for different values of force of impact mass (different heights of impact mass drop). The tests were aimed at determining the impact of dynamic loads on the 
characteristics of leg's operation. It was assumed that the energy and load waveforms during field tests are similar to those in real conditions.

One of the aims of the study is also to approximate the problem associated with the proper selection of the system protecting the leg mounted in a roof support against the negative effects of the dynamic impact of the rock mass.

\section{Analysis of dynamic rock mass impact}

Rock mass impacts underground mining excavations as a result of mining operation. This interaction can be static or dynamic, and is directly transferred to mining roof support.

An example of the static impact of a rock on a powered roof support is the phenomenon of loading it with the weight of overlying rocks. It occurs in the case of roofs with very low durability or with completely or partially destroyed structure. The reaction of the roof support in such conditions is largely dependent on the weight of the rock mass impacting on it. When static value of impact is lower than working support (bearing) capacity of the roof support, no dynamic phenomena occur. In the case of exceeding the value of the working capacity, however, the roof support tightens. This is a result of activation of a safety system, which in this case allow to change the dimensions of the roof support. Such system in a roadway support is based on a sliding connectors [10-12], while in a longwall powered roof support, it is based on fluid flowing out of spaces under the leg's piston through a working or bypass valve, and unit convergence (decreasing its height). The tightening process of the longwall support due to the weight of loosely deposited rock masses in the roof is difficult to stop because the hysteresis of the operation of the working or relief valves. An additional obstacle is the need to slow down the movement of rock masses. To interrupt the tightening process for this type of load is only possible if the weight of the rock masses decreases as a result of the spontaneous formation of the natural roof. In this case, the rock mass moves. If the load is above the yield capacity, the roof support is fully tightened which leads to all overload consequences $[5,6,13]$.

The consequences of such an impact recorded in the mining excavations indicate repeated violation of the permissible load values that can be transferred by the applied support system.

In the case of coarse solid and strong rock deposits in the layers above the operating areas, apart from the static pressure, manifested by the settling of the roof and the heave of the floor in the excavation, other phenomena include rock mass tremors. They are mainly caused by layers cracking. These are sudden and dynamic phenomena that may lead to dangerous consequences. In a short time, there is a significant increase in the rock mass load impacting on the excavation, and consequently also on the roof support. 


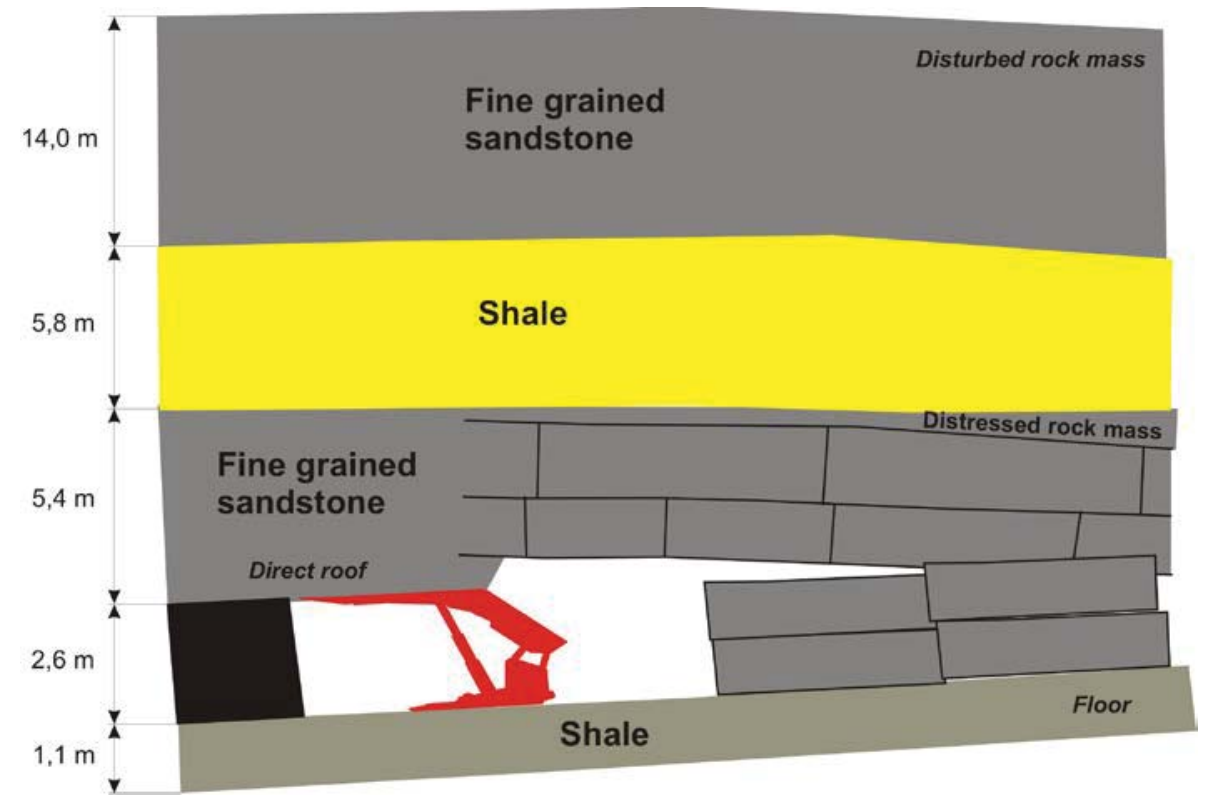

Fig. 1. Distressed rock mass.

Practical tests show that the presence of strong mining tremors during mining operation or after its completion, are likely to cause rock bursts due to the presence of thick, uniform rock layers of high strength deposited above the rock mass. The thickness of those layers (not less than $20 \mathrm{~m}$ ) and their uniformity, which are expressed primarily by the lack of distinct bottoms surfaces, are essential $[5,13]$.

The analysis presented in the paper includes the influence of the dynamic impact of the rock mass in one of the hard coal mines in Poland.

The dynamic impact of the rock mass was recorded in the longwall 7, seam 409, in the Wujek Śląsk Mine, located at a depth of about 985 to $1,025 \mathrm{~m}$.

The seam in that area is characterized by thickness of $2.4 \div 2.6 \mathrm{~m}$ and is inclined towards the south and south west at approx. $3 \div 8^{\circ}$ angle. There is a fine-grained sandstone with a thickness of $5.4 \mathrm{~m}$ deposited in the roof of the subject seam with liner sandy shale in the floor. Above it is a layer of clay slate with a thickness of $1.1 \mathrm{~m}$, below which alternately occur layers of sandstone and sandy shale with a thickness of $11.0 \mathrm{~m}$. The layers are presented in Figure 1. A high energy tremor, $4 \times 10^{9} \mathrm{~J}$, occurred in that area and was located in the distance about $120 \mathrm{~m}$ before the front areas of the longwall area 7, and about $30 \mathrm{~m}$ south of south heading. The analysis was conducted for these real rock dynamic conditions and involved leg's control system of a roof support operating in the subject area. The results are presented herein.

\section{Leg's control system test}

Flow studies in hydraulic systems protecting the legs against overloads were first applied with the introduction of power hydraulics, mainly in powered roof supports. The research was aimed at determining the dependency of the volume flow of the working fluid depending on the pressure. The tests were carried out for individual components as well as for the whole hydraulic system. Particularly important in this system are the systems protecting the legs against dynamic overload caused by rock mass. The analysis and flow tests concerned systems operating at extremely high pressures up to $100 \mathrm{MPa}$. These flows 
are classified as violent, as in such cases the Reynolds number exceeds $10^{5}$, and in occasional cases even $10^{6}$. For flows with such a high Reynolds number in hydromechanics, the current calculation methods based on the Bernoulli equation cannot be used. In the case of dynamic load impacting on the support unit, the fluid flow rates in its hydraulic systems are estimated to be several dozen or even hundreds of $\mathrm{ms}^{-1}$. In addition, there are difficulties in assessing the phase of such flow. This is related to the operation of pumps that pump the fluid along with the sucked air, and therefore the fluid should be treated as a two-phase system.

Consequently, the process of studying such phenomena is very complex. From a practical point of view, the most credible is bench testing. It guarantees reliable reproduction of the actual operating conditions of the roof support or hydraulic leg. It also seems appropriate to supplement the field research with model studies. Numerical computational methods using ANSYS software [14, 15,] provide great possibilities for simulation studies of flow phenomena. They can be applied to model a number of phenomena occurring during the dynamic loading impacting on the roof support, such as the effect of the boundary layer, cavitation, biphasic liquid, and to a large extent change the physical and chemical properties of the liquid. Simultaneous use of computational methods based on specialized software and bench testing provides optimal cognitive effects and enables the utilization of utilitarian applications.

An example of a bench test that reliably reproduces the dynamic impact of a rock mass on a powered support section is the load-bearing test on a hydraulic leg.

By impacting the leg with impact mass it is possible to obtain certain flow values in the safety system. By selecting the proper diameter of the leg and the impact mass, the flow characteristics in the entire leg's control system can be determined.

The tests were based on a control system consisting of a DOH DN12 valve block equipped with a pressure control valve to which the SP10.C valve was connected via a DN19 connection type ZRP and a DOH valve connected via a M45x2 connection, as presented in Figure 2.

The purpose of the study was to evaluate the hydraulic system of the leg with the control system to avoid damage caused by high-energy rock mass tremors [2]. These tests were aimed at checking the correctness of the control system of the support's leg with the hydraulic system to meet the requirements of yielding resulting from the Regulation of the Minister of Energy on OSH $§ 523 \mathrm{sec}$. 2. The subject leg and the hydraulic system was spread between a traverse and the foundation with the pre-support and then loaded with a free-fall impact mass. The setting and yielding was conducted by supplying the leg with hydraulic fluid from the pump station. Measurement and registration of selected physical parameters necessary to assess the dynamics of the leg were performed using specialized apparatus [16].

The method of mounting the leg and the layout of its control system during the dynamic test of the free fall impact mass is shown in Figure 2. 


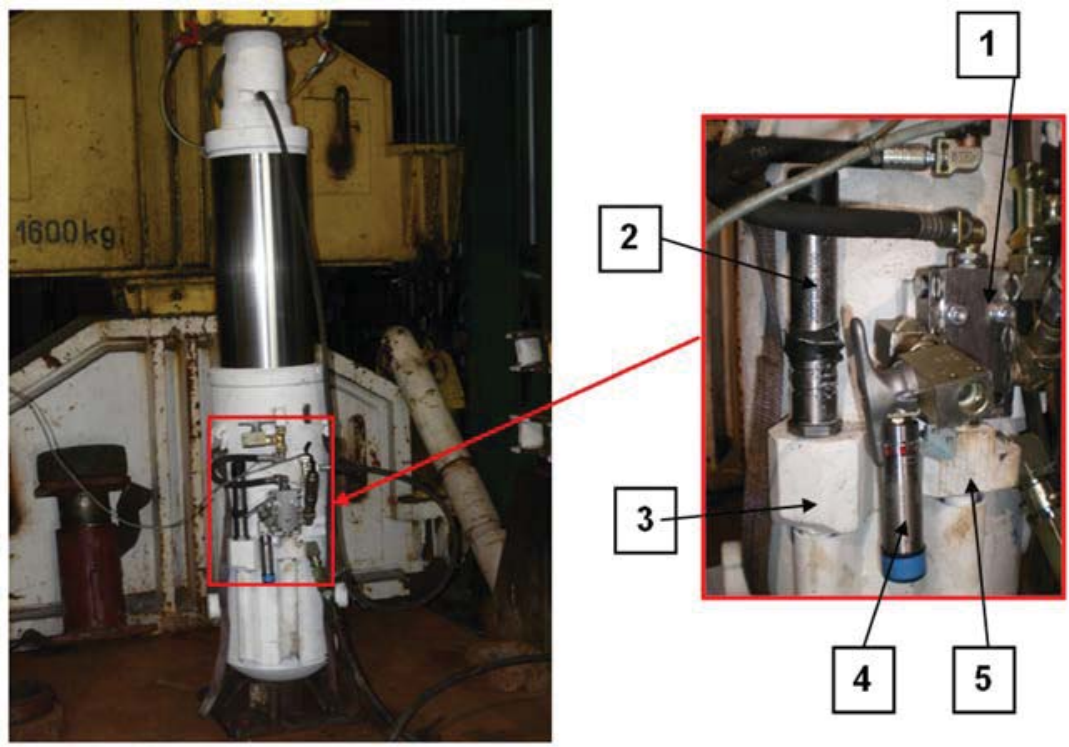

Fig. 2. The $Ø 320$ two-telescopic hydraulic leg and the control system during the dynamic impact mass test.

The tests involved a hydraulic leg type 320/305/250/230x1351, applied to a KHW12/28 POz roof support with a support system (DOH DN12 valve block type 20100312 0502 with a SP10.C valve, and a DOH valve type 20200345 1000) [16]. The impact mass test was carried out in a Central Mining Institute's testing rig located in Łaziska, Poland. The leg was hit with a free falling impact mass of $20 \mathrm{t}$, from six different heights $(\mathrm{h}=0.20$ $\mathrm{m} ; \mathrm{h}=0.230 \mathrm{~m} ; \mathrm{h}=0.35 \mathrm{~m}, \mathrm{~h}=0.40 \mathrm{~m} ; \mathrm{h}=0.45 \mathrm{~m}$ ). The study of the hydraulic support system excitation of the subject leg was based on the spreading of the rack in a rigid frame to its yielded load-bearing capacity (34 MPa). Then, the leg was yielded by applying to the connected DOH DN12 valve block, according to the hydraulic pattern, the set pressure set at 20, 25 and $30 \mathrm{MPa}$. Pressure values were measured and recorded in the space under the piston and the space over the piston in the DOH DN 12 valve block [16].

The effectiveness of the support system of the test leg is shown in Figure 3. The system comprised the DOH DN 12 valve block type 201003120501 (with a check valve controlled with a pressure; item 1, Fig. 2) to which the SP10.C valve was connected (item 4, Fig. 2) with the DN19 connection type ZRP (item 5, Fig. 2) and the DOH valve type 202003451000 (item 2, Fig. 2) connected with the M45x2 terminal (item 3, Fig. 2).

The time waveforms of the pressure changes shown in Figure 3 confirm the effectiveness of the DOH DN12 valve type 201003120502 with the valve SP10.C (valve setting $p_{r}=34 \mathrm{MPa}$ ) and the DOH valve 202003451000 (valve setting $p_{r}=37 \mathrm{MPa}$ ). 


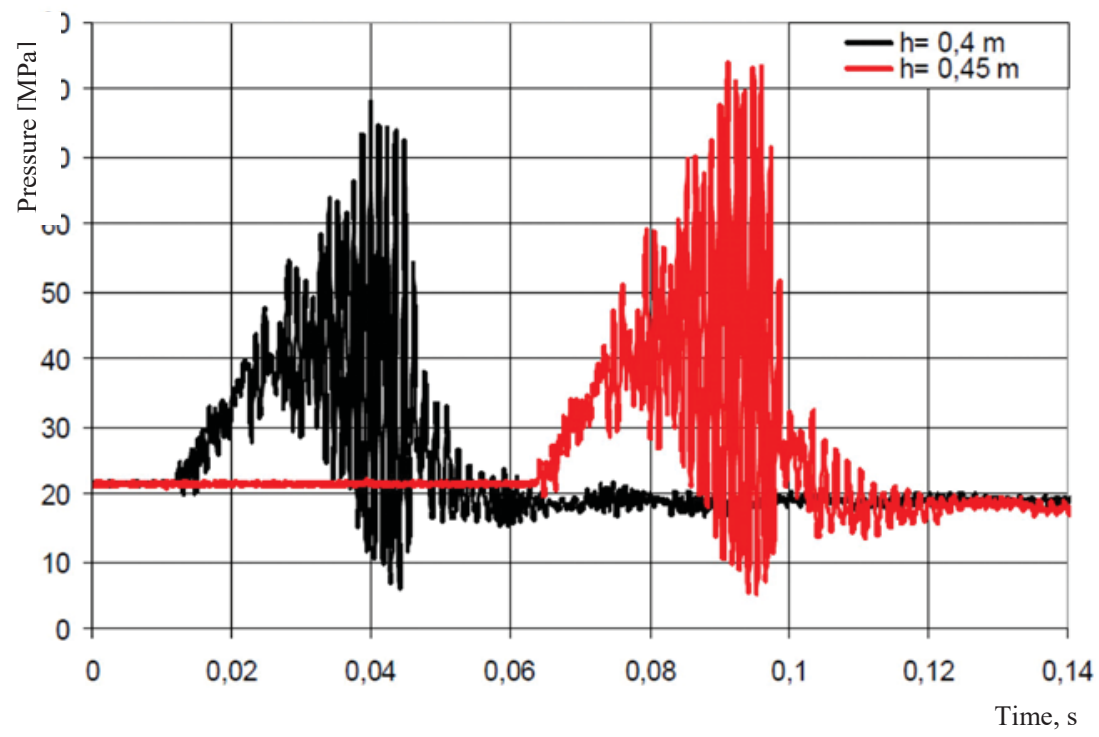

Fig. 3. Time change waveforms of pressure during dynamic load impacting on the hydraulic leg with a control system for two different heights of impact mass drop [10].

The obtained results indicate that the tested support system of the leg along with the increase of the impact energy, stabilizes the pressure in the leg at level about $22 \mathrm{MPa}$. At the same time, the DOH valve type 202003451000 reducing the pressure in the leg releases a much greater amount of fluid at the impact mass drop from $\mathrm{h}=0.45 \mathrm{~m}$ than when released from $0.4 \mathrm{~m}$. All hydraulic components of the leg as well as the entire control system retained its functionality and tightness.

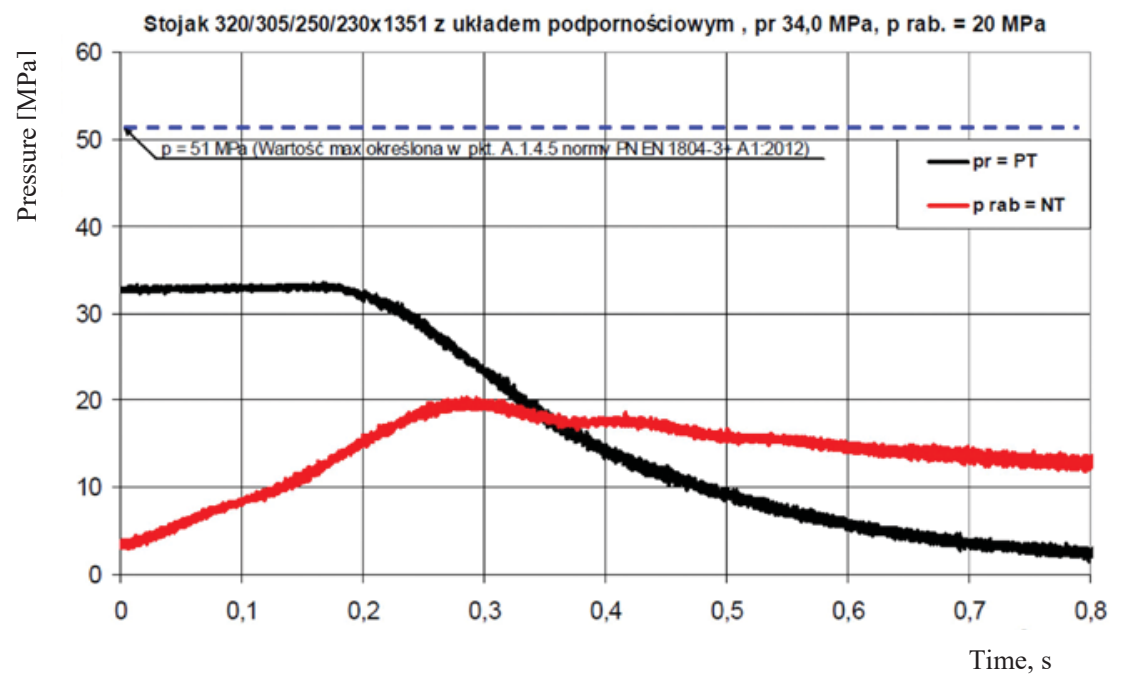

Fig. 4. Changes in pressure values in the space under and over the piston [10].

Pressure values were also recorded over and under the space of the leg's piston. Time waveforms of these values are presented in Figure 4. The analysis of the waveforms suggest that the recorded values fall within the acceptable range. Pressure of $34 \mathrm{MPa}$ is generated in the valve block during dynamic tests, while at drawing off the leg, the pressure in the space 
over the piston is $30 \mathrm{MPa}$. Table 2 lists the maximum pressures and delay times during the overload test.

Table 2. Maximum pressure values and delay times during the overload test.

\begin{tabular}{|c|c|c|c|}
\hline $\begin{array}{c}\text { Drop } \\
\text { height }[\mathbf{m}]\end{array}$ & $\begin{array}{c}\text { Energy of } \\
\text { impact mass, } \\
\text { Eu [kJ] }\end{array}$ & $\begin{array}{c}\text { Maximum recorded } \\
\text { pressure (MPa) }\end{array}$ & Overload test time [s] \\
\hline 0.20 & 4 & 35 & 0.02 \\
\hline 0.30 & 5 & 45 & 0.08 \\
\hline 0.35 & 6 & 43 & 0.12 \\
\hline 0.40 & 7 & 78 & 0.04 \\
\hline 0.45 & 8 & 84 & 0.1 \\
\hline
\end{tabular}

\section{Conclusion}

When operating in underground excavations, the powered roof support is exposed to external static and dynamic loads. In either case, its response can be dynamic. In the case of static load of the roof support resulting mainly from the gravitational pressure of the rocks deposited over the subject area, the dynamic response can occur only when the critical mass exceeds the working load. On the other hand, the occurrence of dynamic phenomena in the rock mass (bursts, tremors) directly causes a dynamic response of the roof support.

The most important element of the powered roof support that carries these loads is the hydraulic leg. As the basic support element of the powered support unit, it also determines its safety and performance. It is a double acting actuator, which mainly works as a compression element. Selection of technical parameters of the leg for specific mining and geological conditions is extremely significant due to requirements for the acquisition of static and dynamic load, and permissible values of overload. This particularly refers to dynamic loads.

The research allowed to determine the characteristics of its work during dynamic load and to determine whether the tested leg is characterized by an overload greater than the maximum weight with which the rock mass will impact on the roof support. The maximum overload capacity of the leg was analysed for the case of clamping of the excavation at the maximum speed resulting in the liquid flowing through the hydraulic valve from the space under the piston.

The results indicated that the valve block used with the SP10.C valve was more effective than expected. The effectiveness of the safety valve with the preset pressure $p_{r}=$ $37 \mathrm{MPa}$ increases with the increase of the impact energy.

It can be assumed that the results obtained are very good and the methodology used enables an objective assessment of applied legs. However, it should noted that in real conditions may occur loads with different characteristics (e.g. longer operating time) than load values simulated during the tests.

The results obtained prove that the research is valuable, justified, and that it is necessary to continue the research.

The work was carried out within the project 'Innovative electrohydraulic control system for powered roof support' No. POIR.01.01.01-00-1129/15. Intelligent Development Operational Programme 2014-2020 carried out by the National Centre for Research and Development. 


\section{References}

1. R. Patyńska, Zagrożenia tapaniami (2008 - 2017). Raport roczny o stanie zagrożeń naturalnych $i$ technicznych $w$ górnictwie węgla kamiennego, The Central Mining Institute, Katowice (2017)

2. S. Prusek, S. Rajwa, A. Walentek, W. Masny, $3^{\text {rd }}$ International Symposium on Mine Safety Science and Engineering, Paper No. 148, Montreal (2016)

3. S. Prusek, S. Rajwa, A. Wrana, A. Krzemień, International Journal of Mining, Reclamation and Environment 31/8 (2017)

4. S. Prusek, M. Płonka, A. Walentek, Arabian Journal of Geosciences 3/9 (2016)

5. A. Biliński, Prace Naukowe - Monografie CMG KOMAG, Gliwice (2005)

6. S. Prusek, Stability of longwall workings during the operation of coal deposits based on cave mining (in Polish), The Central Mining Institute, Katowice (2016)

7. D. Szurgacz, Polské hornictví v souèastné dobì, VIII. Mezinárodní konferencje, Strojní zařizení použivaná při hornické činnosti a činnosti prováděné hornickým způsobem, jejich bezpečnost a nové trendy č. 101, 27-28.4.2017 v Ostravici (2017)

8. D. Szurgacz, Wiadomości Górnicze 10 (2011)

9. K. Stoińsk, J. Gil, XXII International Conference TEMAG 2014, Gliwice - Ustroń 249-255 (2014)

10. J. Brodny, Archives of Mining Sciences 56/2, 303-318 (2011)

11. J. Brodny, Archives of Mining Sciences 57/1, 209-227 (2012)

12. M. Tutak, A. Dymark, T. Dzitkowski, MECHANIKA 2017, Proceedings of the 22nd International Scientific Conference, Kaunas 2017, 383-386 (2017)

13. K. Stoiński, Napęd i Sterowanie 7/6 (2006)

14. L. Doległo, J. Gil, K. Stoiński, Maszyny Górnicze 4 (2009)

15. D. Szurgacz, Mining Science 22/2, 171-179 (2015)

16. GIG Test Report no. 57205506-182. Technical test of a hydraulic leg type $320 / 305 / 250 / 230 \times 1351$, applied to a KHW-12/28 POz roof support with a support system (DOH DN12 valve block type 201003120502 with a SP10.C valve, and a DOH valve type 202020200345 1000) (2015) 